ЕКСПЕРИМЕНТАЛЬНА ПЕРЕВІРКА ОРГАНІЗАЦІЙНО-ПЕДАГОГІЧНИХ УМОВ РОЗВИТКУ ПРОФЕСІЙНОЇ КУЛЬТУРИ МАЙБУТНІХ ВІЙСЬКОВИХ ЛІКАРІВ У СИСТЕМІ ВІЙСЬКОВО-МЕДИЧНОї ОСВІТИ

\title{
EXPERIMENTAL VERIFICATION OF ORGANIZATIONAL AND PEDAGOGICAL CONDITIONS OF DEVELOPMENT OF PROFESSIONAL CULTURE OF FUTURE MILITARY DOCTORS IN THE SYSTEM MILITARY MEDICAL EDUCATION
}

Висвітлено методику й результати проведеного експериментального дослідження 3 вивченням стану та розвитку професійної культури майбутніх військових лікарів е системі військово-медичної освіти. У статmі автор висвітлює результати констатуючого експерименту для участі в якому були запрошені студенти першого і другого курсів медичних університетів, що одночасно проходили військову підготовку в Українській військово-медичній академії за програмою офрічерів запасу медичної служби.

Автор статті зробив аналіз останніх досліджень і публікацій учених, котрі розкривають суть поняття «професійна культура», висвітлив аналогічні розробки в галузі військово-медичної освіти України. Здійснюючи власну експериментальну перевірку, автор спирається на теоретичні напрацювання науковців, у яких розкрито методику «педагогічного експерименту». Протягом педагогічної діагностики було застосовано такі методи дослідження, як незалежна експертна оцінка групою експертів, спостереження, анкетування, бесіда й інтерв'ю. Завданням педагогічного експерименту загалом була перевірка гіпотези дослідження розвитку професійної культури лікарів шляхом створення відповідних організаційнопедагогічних умов, де автор передбачає впровадження когнітивно-направленої технології, застосування експліцитно-психологічного впливу до студентів медиків. У поданій статті автор висвітлює результати констатуючого експерименту, який є початковим в експериментальному дослідженні й дозволяє встановити стан педагогічної системи, що вивчається, реальний рівень сформованості й розвитку профресійної культури студентів. За результатами констатуючого експерименту виявляються причиннонаслідкові зв'язки педагогічного прочесу, відбувається подальша дослідницька робота, яка має на меті впровадження нової педагогічної технології з метою покращення результатів у навчанні й вихованні студентів. Стан сорормованості й розвитку професійної культури майбутніх військових лікарів було досліджено за допомогою таких структурних компонентів профресійної культури, як: когнітивного, комунікативного, мотиваційно-ціннісного, морально-етичного, етнокультурного й організаційного. Висновки дослідження будуть сприяти пошуку більш дієвих педагогічних технологій, досягненню якісних показників у знаннях студентів, набуття ними достатніх просресійних навичок і вмінь. Ключові слова: методика, професійна культура, розвиток, педагогічна діагностика, організаційно-педагогічні умови, майбутні військові лікарі.

The article highlights the methodology and results of an experimental study and development of professional culture of future military doctors in the system of military education. In the article the author highlights the results of the observational experiment in which took part first and second year student of medical universities who were undergoing military training at the Ukrainian Military Medical Academy under the program of medical service reserve officers.

The author of the article analyzed the latest research and publications of scientists that reveal the essence of the concepts of professional culture, highlighted similar developments in the field of military medical education in Ukraine. Carrying out his own experimental verification, the author relies on the theoretical achievements of scientists who have revealed the method of "pedagogical experiment". During pedagogical diagnostics were used such research methods as independent expertevaluation by group of experts, observation, questionnaires, and interviews.

The task of pedagogical experiment as a whole was to test the hypothesis of research of development of professional culture of doctors, by creation of the corresponding organizational and pedagogical conditions where the author provides introduction of cognitive-directed technology, application of explicitly psychological influence to medical students. In this article the author highlights the results of observational experiment, which is the initial in the experimental study, and allows establishing the state of the pedagogical system being studied, the real level of formation and development of professional culture of students. According to the results of ascertaining experiment, causal and consequential connections of the pedagogical process are revealed, further research work is carried out, which aims to introduce new pedagogical technology in order to improve the results in teaching and educating students.

The state of formation and development of professional culture of future military doctors was studied using such structural components of professional culture as: cognitive, communicative, motivational-value, moral-ethical, ethno cultural and organizational. The conclusions of study will contribute to the search for more effective pedagogical technologies, the achievement of quality in students' knowledge, the acquisition of sufficient professional skills and abilities.

Key words: methods, professional culture, development, pedagogical diagnostics, organizational and pedagogical conditions, future military doctors. загальновійськових дисциплін

Української військово-медичної академії
Постановка проблеми в загальному вигляді. Підвищення ефективності системи військовомедичної освіти неможливе без дослідження низки психолого-педагогічних питань, зокрема розвитку професійної культури науково-педагогічних праців- ників, студентів і слухачів вищих медичних закладів України. В умовах євроінтеграції освітнього процесу країни, наближення системи військово-медичної освіти до євроатлантичних стандартів актуальним постає питання проведення експериментальних 
досліджень щодо розвитку профресійної культури майбутніх військових лікарів.

Аналіз останніх досліджень і публікацій. У контексті формування й розвитку професійної культури лікарів в останні роки достатньо уваги привертають праці Е. Белоконева, Ю. Вороненка, О. Гури, Н. Миколаєнка, О Мінцера, В. Краснова, О. Кульбаха, О. Парахіна. Питанням удосконалення кваліфікації викладачів військово-медичної освіти присвячені роботи Я. Радиш, А. Романенка й В. Солярика. Особливості підготовки військових лікарів у системі військово-медичної освіти й підвищення їх професійного рівня системно розкриті у працях М. Бойчака, Л. Голіка, В. Жаховського, Б. Клішевича, Ю. Румянцева.

Педагогічна діагностика та експериментальна перевірка підготовки майбутніх спеціалістів у теорії і практиці педагогіки досліджена у працях відомих педагогів С. Архангельського, Ю. Бабанського, В. Журавльова, В. Міхеєва, А. Піскунова тощо. У вітчизняній педагогіці методика педагогічного дослідження й експерименту, обробка їх результатів викладені в роботах П. Волкова, Б. Гершунського, С. Гончаренка, І. Підласного, В. Ягупова та інших. Водночас проблема фрормування професійної культури майбутніх військових лікарів в умовах російсько-української війни на сході України та пандемії COVID-19 залишається недостатньо розробленою.

Мета статті. Метою статті $€$ визначення методики і стану експериментальної перевірки фрормування професійної культури майбутніх військових лікарів. Експериментальне дослідження повинно здійснити доказову перевірку гіпотези дослідження щодо розвитку профресійної культури, передусім свідомості військових лікарів, щодо виконання своїх обов'язків, шляхом створення відповідних організаційно-педагогічних умов, упровадження когнітивної направленої технології, застосування експліцитно-психологічного впливу до студентів медичних закладів.

Виклад основного матеріалу. Сучасний етап формування й розвитку військово-медичних сил України потребує належної оцінки стану й перспектив підготовки майбутніх військових лікарів у системі військово-медичної освіти, зважаючи на загрози та потреби підготовки високопідготовлених фрахівців. Виникає необхідність отримання обґрунтованих наукових результатів педагогічної оцінки шляхом педагогічних досліджень. Із метою вивчення окремих аспектів професійної культури майбутніх військових лікарів, дослідження висунутої гіпотези щодо моделі й методики її розвитку постає потреба проведення педагогічного експерименту, і як результат, відбувається пошук нової сучасної технології педагогічного процесу, виявлення необхідних умов реалізації завдань щодо якісної підготовки майбутніх військових лікарів в умовах сьогодення.
Ю. Бабанський визначає поняття «педагогічний експеримент» як комплекс методів дослідження для перевірки вірогідності педагогічних гіпотез. У роботі «Проблеми підвищення ефективності педагогічних досліджень» дослідник зазначає, що метод педагогічного експерименту дозволяє: установити характер зв'язків між різними компонентами педагогічного процесу, між фракторами, умовами й результатами педагогічного впливу; між компонентами педагогічного процесу; перевірити ефективність педагогічних нововведень; порівняти ефективність різних фракторів або змін у структурі процесу та вибрати найкраще їхнє поєднання для певних умов; виявити необхідні умови для реалізації певного комплексу завдань відомими засобами; виявити особливості перебігу процесу в нових умовах [1, с. 99-100].

Педагогічна наука широко використовує теоретичні засади в галузі експериментальних педагогічних досліджень таких учених, як Ю. Бабанський, С. Гончаренко, О. Данилов, В. Загвязинський, Л. Занков, А. Піскунов, Н. Кузьміна та інші. С. Гончаренко надає розгорнуту фрорму педагогічного експерименту, який повинен спиратись на весь арсенал дослідницьких методів, що веде до нагромадження емпіричного матеріалу, забезпечує перехід від спостереження до глибокого пізнання й вироблення практичних рекомендацій [2, с. 178]. Учений показує, що педагогічний експеримент передбачає дослідження педагогічних процесів у спеціально створених умовах, спостереження за їх перебігом, керування ними, а за потреби - відтворення. «Експериментом $€$ дослідження педагогічного процесу шляхом унесення в нього принципово важливих змін, відповідно до поставлених завдань та висунутої гіпотези. Це дозволяє розкрити взаємозв'язки між явищами, котрі вивчаються, й описати їх якісно й кількісно» [2, с. 178].

Під час проведення педагогічного експерименту дослідниками використовуються різноманітні методи: спостереження, бесіди, опитування, анкетування, інтерв'ю, застосування різних ситуативних моделей тощо. Вчені, які науково обґрунтували підходи до проведення експерименту, передбачають утручання дослідника в педагогічний процес у визначених умовах з метою його вивчення та подальшої корекції.

Завданням педагогічного експерименту, що проводиться нами, є з'ясування порівняльної есрективності застосованих у педагогічній практиці методів, технологій, нових прийомів, фрорм роботи. В межах нашого дослідження постало завдання визначити рівень сорормованості й розвитку профресійної культури майбутніх лікарів у системі військово-медичної освіти. За типологією проведення експерименту автор на початку дослідження провів констатуючий експеримент, який дозволив установити стан предмету дослідження, 
виявити рівень сорормованості й розвитку професійної культури майбутніх військових лікарів на початку їх навчання у вищому медичному закладі з метою її подальшого розвитку й фрормування.

У проведенні експерименту 3 вивченням кола питань формування й розвитку професійної культури майбутніх військових лікарів взяли участь 220 студентів Національного медичного університету імені О.О. Богомольця та Київського медичного університету всіх основних спеціалізацій медичних напрямів навчання. 3 метою проведення експерименту безпосередньо були використані такі методи дослідження, як метод незалежної експертної оцінки групою експертів, методи спостереження, бесіди, анкетування й математичної обробки інформації. В експерименті переважно були охоплені студенти першого і другого курсів зазначених вище медичних університетів, які прийняли рішення навчатись за програмою підготовки офріцерів запасу медичної служби в Українській військово-медичній академії.

У 2018 році у процесі констатуючого експерименту було уточнено чинну систему організаційнопедагогічних умов із формування професійної культури майбутніх військових лікарів у системі військово-медичної освіти. Стан сорормованості й розвитку професійної культури майбутніх військових лікарів було вивчено шляхом визначення рівня таких компонентів професійної культури, як когнітивного, комунікативного, організаційного, морально-етичного, поведінкового й етнокультурного.

Зважаючи на те, що кожний студент проходить у своєму навчанні стадії становлення й адаптації до умов навчання, надалі здійснює нарощування зусиль 3 інтелектуального, духовного, фрізичного й культурного розвитку, і нарешті набуває практичних навичок і вмінь, проходять і зміни у відповідних програмах навчання медичних закладів. Надалі протягом навчання у студентів якісно змінюються показники компонентів профресіональної культури, котрі були встановлені в констатуючому експериментальному дослідженні. Показники покращуються протягом навчання в університеті, чому сприяє проведення подальшого фрормувального педагогічного експерименту. Формувальний (навчальний, перетворювальний) експеримент спрямований на вивчення динаміки розвитку педагогічних явищ, які досліджуються за умови активного впливу дослідника на умови навчальної діяльності.

Першим досліджуваним показником проведеного нами констатуючого експерименту було визначення рівня сорормованості й розвитку когнітивного компоненту профресійної культури майбутніх військових лікарів. Результати опитування засвідчили, що низький рівень розвитку когнітивного компоненту встановлено у $32 \%$ опитуваних. Студенти намагались використовувати зручну оперативну форму отримання інформації, що спо- стерігалось під час бесід, анкетування, а інколи й інтерв'ю, де опитувані максимально робили спроби використовувати мобільні телефони, інші пристрої з метою якісної відповіді, інколи ухиляючись від глибокого осмислення й аналізу інформації та напруження пам'яті. Середній рівень розвитку когнітивного компоненту показали 58\% опитуваних, що свідчить про якісний рівень їх попереднього профресійного відбору в університет за фрахом і перспективу подальшого послідовного інтелектуального росту. Більшість студентів здатні аналізувати надану їм інорормацію, мають середній загальноосвітній рівень і відповідні когнітивні здібності. Високі показники показали лише 10\% студентів, які змогли впевнено, швидко і якісно відповісти на поставлені питання. Звичайно, необхідно зазначити що велика шкала розбіжностей когнітивних показників виникає у студентів медичних закладів між групами, які навчаються на бюджетній формі навчання і групами лікарів, що навчаються на контрактній основі. Високі показники когнітивного компоненту показали достатньо вмотивовані до навчання студенти фракультету підготовки військових лікарів.

Комунікативна культура лікаря є вагомою частиною професійної культури й компетентності лікаря. Майбутні лікарі мають бути готовими до різнобічних ділових контактів як із колегами, так із пацієнтами. У процесі дослідження нами встановлено, що комунікативна культура майбутнього лікаря фрормується на ґрунті мотиваційних й особистісних компонентів, прояву загальної культури, комунікативних знань та навичок. Для визначення рівня сорормованості комунікативного компоненту нами були застосовані анкетування, спостереження, бесіди й інтерв'ю. Використано методику «Виявлення комунікативних здібностей» (В. Бойка), діагностику здатності до співпереживання (С. Дідато), комунікабельності особистості (тест Ряховського).

Використовувались анкети відкритого й закритого типів, де студенти обирали альтернативну відповідь або висловлювали свої думки. За допомогою бесід й анкетування нами було ретельно досліджено рівень набутих студентами комунікативних знань, розуміння того, як студенти усвідомлюють потребу в підвищенні комунікативного рівня. Внаслідок проведеного констатуючого експерименту щодо рівня сорормованості комунікативного компоненту встановлено, що низький рівень розвитку комунікаційних умінь і навичок наявний у 25\% студентів і є достатньо низьким для майбутніх військових лікарів. Середній рівень показали більшість опитуваних (53\%), високий виявлено у $22 \%$ студентів.

Нами також установлено що $є$ труднощі й бар'єри у процесі комунікації студентів із викладачами й комунікації взагалі. Серед комунікативних труднощів варто назвати такі, як: публічність 
у спілкуванні, страх аудиторії, хвилювання, нерішучість; низький рівень навичок у спілкуванні; низька потреба до самовдосконалення комунікативних навичок і вмінь; неготовність вести діалог із викладацьким складом і студентами старших курсів. Вивчення комунікативних навичок, які будуть потрібні військовим медикам, показало: неготовність до командно-адміністративного (керівного) стилю керівництва військовим колективом, статутної комунікації, навичок військової субординації (у процесі занять із військово-спеціальної підготовки за програмою підготовки офріцерів запасу).

Досліджуючи мотиваційно-ціннісний складник професійної культури майбутніх військових лікарів під час констатувального експерименту, ми спиратись на психологічні аспекти професійного становлення й досліджували мотиви, які спонукали особистість до обрання профресії. Варто погодитись із думкою науковців О. Бодальова і О. Черних [3, с. 162], які дають оцінку мотивів у виборі професії, серед них: матеріальна зацікавленість, прагнення зміцнити свій соціальний статус, бажання самостверджуватись та впливати на інших людей, наукові або альтруїстичні інтереси.

Нами було застосовано методику «Ціннісні орієнтації» М. Рокіча [4, с, 246]. Студент мав проаранжувати низку цінностей, притаманну професії лікаря за значимістю. Нами були запропоновано розподілити ціннісні мотивації лікаря на три групи: необхідні, користі й неприпустимі. Було також запропоновано проаранжувати мотиви щодо здобуття професії лікарям та якісного оволодіння фахом, які ми розподілили на такі групи: прагматичні (матеріальна винагорода, зарплата, інші шляхи здобуття матеріальних благ); наукові мотиви (бажання сумлінно вчитись, набувати знань, навичок, вмінь, робити наукові винаходи); альтруїстичні мотиви (якісне виконання обов'язків, покращення здоров'я пацієнтів, тощо).

Узагальнення результатів дозволило визначити рівні мотиваційно-ціннісної сорери майбутніх військових лікарів у перший рік навчання, які було розподілені на три рівні. Результати анкетування показуют, що низький рівень мали 20\% студентів, $61 \%$ - середній і тільки 19\% - високий. Високий рівень розвитку готовності студента до роботи як лікаря зумовлений високою альтруїстичною мотивацією у виборі професії, присвятити себе завданню рятувати й лікувати людей за будь-яких обставин. Низька мотивація свідчить про те, що не всі студенти самостійно прийняли свідоме рішення стати лікарем, значна частина спиралась на думку й рішення батьків. Більшість студентів головним мотивом навчальної діяльності вважають отримання диплому з вищою освітою лікаря, ставлення до якісного навчання знаходиться у стадії розвитку. Водночас система навчання змушує студентів швидко змінювати ставлення до навчання, зважа- ючи на проміжний професійний незалежний тест за результатами річного навчання, де студенти 3 низькими показниками відраховуються.

Велике значення в підготовці майбутніх лікарів має фрормування морально-етичного складника професійної культури. Л. Богданова визначає профресійну культуру як органічний сплав кваліфрікації й моральності, що фрункціонує на основі трудової моралі [5, с. 388]. Світова наука завжди тримала в полі зору морально-етичні якості лікарів. Неможливо залишити поза увагою «Клятву», «Закон Гіппократа» [6, с. 43], «Етику» Ібн-Сіни, «Щоденник старого лікаря» «Листи з Гейдельберга» М. Пирогова. Серед сучасних дослідників цікавими $€$ роботи Х. Мазепи (організаційно-педагогічні умови виховної роботи в медичному коледжі) [7], Л. Переймибіда (розвиток деонтологічної культури учнів медичного ліцею) [8].

У процесі опитування аспектів морально-етичної поведінки на етапі констатуючого експерименту нами було надано перелік питань із метою вивчення стану сорормованості професійних та етичних цінностей. Увага була звернута на проблему самооцінки морально-етичних якостей майбутнього лікаря в реальному середовищі. Мета була не тільки встановити стан сформованості а й надати молодій особі настанови щодо адекватної самооцінки з метою зменшення таких вад, як егоцентризм, цинізм, байдужість, корисливість, надати орієнтири для подальшого самовдосконалення в деонтологічній культурі. За показниками опитування 23\% показали низький рівень сформованості морально-етичного компоненту професійної культури лікаря, 62\% - середній і лише 15\% - високий.

Додатково нами було вивчено етнокультурний рівень студентів і його самооцінку. Питання торкались знань історії України, українського війська, народних традицій, пісень, участі в конкурсах, фестивалях, обговоренню телепередач, читання книг, використання державної мови, тощо, що стосувалось кола питань із фрормування етнокультурного рівня. Показники опитування свідчать про те, що низький рівень показали $30 \%$ опитуваних, $55 \%$ - середній і 15\% - високий.

Вивчаючи організаційний компонент, ми ставили за мету з'ясувати вміння майбутнього лікаря самостійно організувати як власну роботу, так і роботу невеликої групи колег. 22\% респондентів показали низький рівень, що засвідчило небажання окремих студентів працювати в команді, брати участь у масових організаційних заходах, проявляти ініціативу й лідерські якості. 54\% визначено як середній рівень і тільки $24 \%$ - як високий. Студенти 3 високим рівнем в окремих випадках займались волонтерською роботою, активно брали участь у громадському житті колективів, активно включились у роботу студентської ради тощо. 
Нами було проведено дослідження визначення сорормованості й розвитку професійної культури майбутніх військових лікарів у системі військовомедичної освіти з вивченням її структурних компонентів. Узагальнюючи результати опитування під час констатуючого експерименту, було встановлено, що високий рівень мають $17,5 \%$ опитуваних студентів, низький - 25,3\% а середній - 57,1\%. Було використано методи незалежних експертних оцінок, спостереження, анкетування й інтерв'ю. Проведення констатуючого експерименту дозволило з'ясувати рівень сорормованості й розвитку професійної культури на початку навчання у вищому медичному закладі. Зважаючи на те, що більшість опитуваних навчаються за програмою підготовки офріцерів запасу медичної служби, є всі підстави вважати що якісні показники, особливо когнітивний, організаційний і морально-етичний будуть значно покращені в системі навчання майбутніх військових лікарів.

Висновки. Отримані результати проведеного констатуючого експерименту дозволили нам визначити найбільш та найменш розвинені рівні сорормованості й розвитку визначених компонентів професійної культури майбутніх військових лікарів. Результати дослідження є підґрунтям для продовження проведення фрормуючого експерименту 3 метою підтвердження гіпотези наукового дослідження. Наведене у статті дослідження $є$ актуальним в умовах сьогодення, зважаючи на потребу в якісній підготовці майбутніх військових лікарів, а також 3 огляду на військові загрози й епідеміологічну обстановку. Висновки і практичні рекомендації дослідження будуть сприяти впровадженню нових методик, удосконаленню навчальних програм і застосуванню нових педагогічних технологій із метою розвитку знань, умінь і навичок майбутніх військових лікарів.

\section{БІБЛІОГРАФІЧНИЙ СПИСОК:}

1. Бабанский Ю. Проблемы повышения эффрективности педагогических исследований. (Дидактический аспект) : монография. Москва : Педагогика, 1982. 192 с.

2. Гончаренко С. Педагогічні дослідження: Методологічні поради молодим науковцям. Київ-Вінниця : ДОВ «Вінниця», 2008. 278 с.

3. Бодальов А. Личность и общение. Москва : Педагогика, 1983. 256 с.

4. Райгородский Д. Практическая психодиагностика: методики и тесты. Москва, 2006. 480 с.

5. Богданова Л. К вопросу о культуре профессионального общения. Юбилейный сб. тр. ученых. РГАФК посв. 80-летию академии. Москва, 1998. $388 \mathrm{C}$

6. Верхратський С. Заблудовський П. Історія медицини : навчальний посібник. 4 вид. Київ : Вища школа, 1991. С. 43.

7. Мазепа X. Організаційно-педагогічні умови виховної роботи в медичному коледжі : автореферат дис. канд. пед. наук. Тернопіль : 2001. 20 с.

8. Переймибіда Л. Організаційні засади діяльності педагогічного колективу з розвитку деонтологічної культури учнів медичного ліцею : автореферат дис. канд. пед. наук. Київ, 2008. 21 с. 